\title{
Mapping of Structurally Controlled Uranium Mineralization in Kadabora Granite, Central Eastern Desert, Egypt Using Remote Sensing and Gamma Ray Spectrometry Data
}

\author{
Hatem Aboelkhair*, Emad Hasan and Haytham Sehsah
}

Damietta University, Faculty of Science, Geology Department, P.O. Box 3417 New Damietta, Egypt

\begin{abstract}
Kadabora younger granite pluton is one of the most promising uranium mineralization plutons in the central Eastern Desert (CED) of Egypt. Airborne gamma ray spectrometry (AGRS) integrated with $\mathrm{ETM}^{+}$remote sensing data to identify and map uraniferous alteration zones hosted in Kadabora pluton. These data were also used to locate more radioactive areas of mineralization, identifying their migration path, and to differentiate between mineralization types. The interpretation of airborne gamma-ray spectrometry shows that the northern part of the pluton contains high concentrations of secondary uranium mineralization, representing the more promising zone in Kadabora pluton. The maximum uranium and thorium concentration is $10 \mathrm{ppm}$ and $20 \mathrm{ppm}$ respectively. Kadabora pluton can be subdivided radiometrically into three parts the southern part with U-leaching, the central part with partly U-enrichment and the northern part with extensive U-enrichment. False color composite (FCC), principal component analysis (PCA), band ratio, intensity hue saturation, and least squares fitting techniques were applied to investigate the uranium-bearing zones. The PCA was the effective technique for mapping the potential alteration zones in the Kadabora area. The integration between airborne gamma ray spectrometry data analysis and ETM+ image processing techniques revealed that concentrations of secondary uranium mineralization are favorably located in the areas of pegmatite associations, and along mainly N-S trending fractures, joints and faults through the effects of hydrothermal solutions and in wadis due to meteoric water effect.
\end{abstract}

Keywords: Kadabora Granite, Remote Sensing, $\mathrm{ETM}^{+}$, Airborne Gamma Ray Spectrometry, Uranium.

\section{INTRODUCTION}

Basement rocks cover about one tenth of the land surface of Egypt forming mountainous terrains in southern Sinai, the Eastern Desert (ED) and the southern part of the Western Desert. These rocks exist in Sinai, the Eastern and Western Deserts of Egypt. Sudan, Ethiopia and Somalia constitute the Nubian Shield that had formed as a contiguous part of the Arabian Shield, prior to the opening of the Red Sea, since less than 30 Ma ago [1].

The Egyptian Eastern Desert is roughly divided into northern (NED), central (CED), and southern (SED) portions by two lines running from Qena to Safaga and from Idfu to Marsa Alam (Fig. 1) [2]. These subdivisions confine parts with common geographic and lithostructural discontinuties [2].

Secondary uranium mineralization is the main target of radiometric exploration, because of its greater economic value compared with primary deposits that originate under magmatic processes. Uranium and thorium show relatively high concentrations in the granitoid rocks compared with the earth's crust. This is due to their incompatible geochemical behavior in the genesis of such rocks either by partial melting of pre-existing rocks or by fractional crystallization of magma [3].

*Address correspondence to this author at the Damietta University, Faculty of Science, Geology Department, P.O. Box 3417 New Damietta, Egypt; Tel: +20 114 4897466; Fax: +20 57 2403868; E-mail: h.aboelkhair@du.edu.eg
The granitoid rocks represent $40 \%$ of the exposed basement rocks in the Eastern Desert of Egypt, from which about $13 \%$ are younger granites [4]. The famous uranium occurrences in Egypt are found in Gabal El Missikat [5], Gabal Um Ara [6], Gabal Gattar [7] and Gabal El Sella [8]. An age-radioactivity relationship has also been established, where the younger granites are found to be generally more radioactive than the older ones, and the highest radioactivity is mainly attained in the late orogenic granite and related rocks [9].

Kadabora is the largest granitic pluton in the central Eastern Desert of Egypt to the north of Mersa Alam (Fig. 2), located between longitudes $34^{\circ} 20^{\prime}$ and $34^{\circ} 33^{\prime} \mathrm{E}$ and latitudes $25^{\circ} 29^{\prime}$ and $25^{\circ} 32^{\prime} \mathrm{N}$. Kadabora granite pluton has been investigated through several studies dealing with its magma source, mineralogy, radioactivity and physical dressing [10-21].

The use of gamma ray spectrometry as a tool for mapping and exploring radioelement concentrations has found widespread acceptance in diverse fields. The method has evolved over several decades and continues to be developed [22]. However, with the development of spectrometers in the $1960 \mathrm{~s}$, the scope of the gamma ray method was expanded to include geological and environmental mapping [23]. Gamma-ray spectrometry can also be used to search for minerals other than uranium, such as heavy minerals, beach sands and phosphates [24, 25].

The present study aims at the delineation and mapping uranium mineralization in Kadabora area, central Eastern 
Desert of Egypt, using integrated remote sensing datasets (ETM and airborne gamma ray spectrometer) with field and laboratory investigation. This objective is also extended to map the different granitic phases of Kadabora pluton and delineate structural trends that control the distribution of the mineralized zones in the study area to conduct an example study needed as a forward step towards the evaluation of such potential areas.

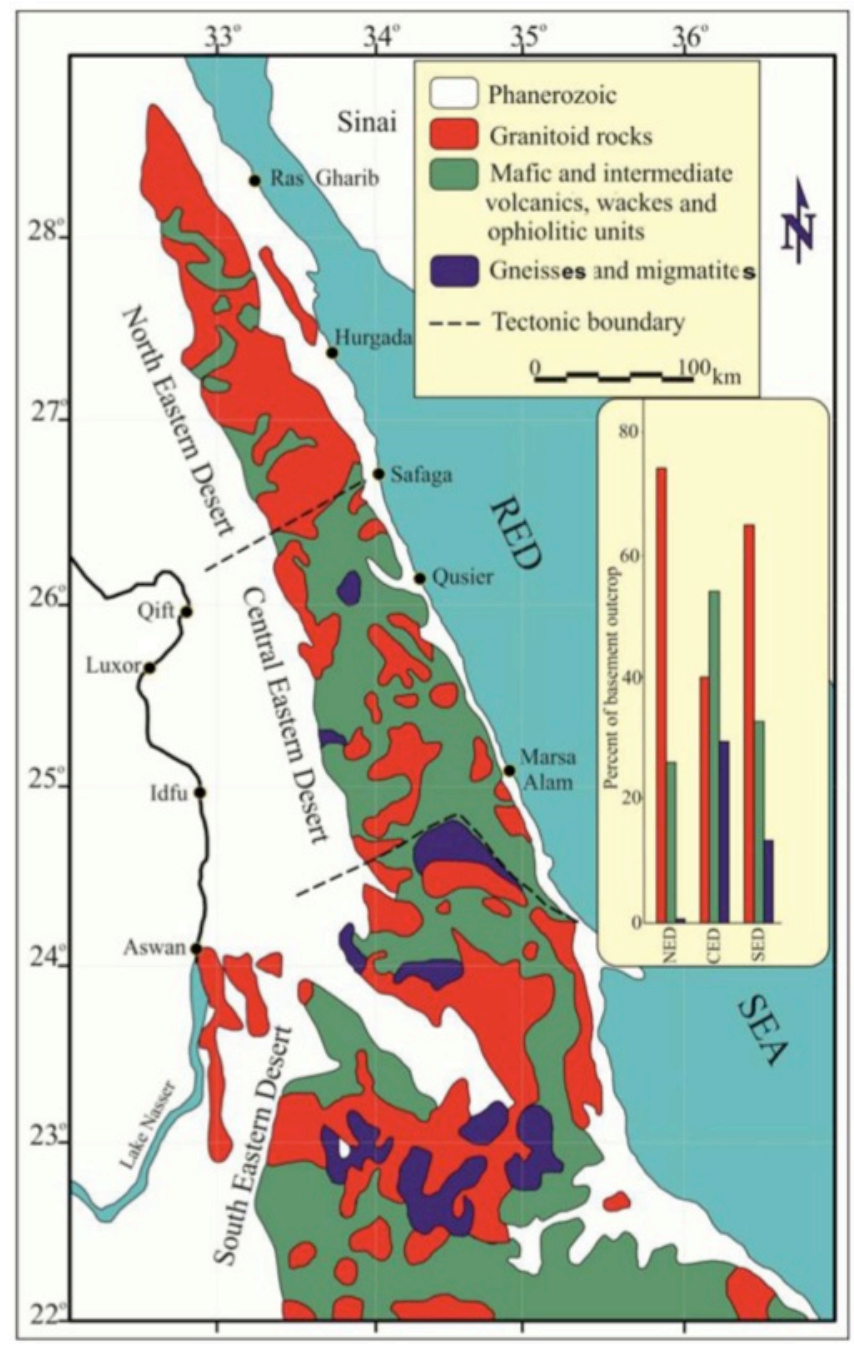

Fig. (1). Simplified geologic map of the Neoproterozoic basement exposed in the Eastern Desert of Egypt. Inset shows relative abundances in the 3 major basement provinces of the Eastern Desert Egypt, (Stern and Hedge, 1985).

\section{GEOLOGIC SETTING}

Kadabora is the largest granitic pluton in the Eastern Desert. It is oval with a NE-SW long extent of about $22 \mathrm{~km}$, and NW-SE short extent of about $16 \mathrm{~km} \mathrm{[19]} \mathrm{it} \mathrm{shows} \mathrm{high}$ relief and sharp contact with the country rocks. The Kadabora area contains different lithologic units including dyke swarms and pegmatites, granitoids, volcanogenic metasediments, metavolcanics, metasediments and metagabbros (Fig. 3). Kadabora represents a post tectonic zoned pluton consisting of monzogranites with only subordinate syenogranites [17] that show potassic-character with scarce sodic tendencies [13]. About 23 pegmatite bodies are found in Kadabora pluton that can be classified into two groups: The first one composed from quartzfeldspar-mica (10 outcrops, mineralized) and the second one composed from quartz-feldspar (13 outcrop, barren) [20].

Dyke swarms of different composition with more or less N-S directions traverse Kadabora pluton (Fig. 3). 2455 dykes were detected within Kadabora pluton [26]. Dyke swarms are classified as felsic, intermediate, mafic and lamprophyre types derived from separate magmas not by magmatic differentiation of a single magma [19]. These dykes pertain to post-granitic dykes [27]. Major valleys, generally trending more or less NE-SW, N-S and NW-SE (e.g. Wadi Abu Dob, Wadi Kadabora El Hamra, Wadi Umm Gheig, Wadi Mubarak, Wadi El Umrah, Wadi Um Graifat and Wadi Kab El Rakab) are filled with Quaternary sediments.

\section{RESULTS AND DISCUSSIONS}

\subsection{Gamma-Ray Spectrometry Data Interpretation}

Airborne Gamma Ray Spectrometry (AGRS) is a powerful method used for measuring $\mathrm{U}, \mathrm{Th}, \mathrm{K}$ distribution in the rocks and to delineate the potassic alteration zones associated with uranium mineralization. AGRS depends principally upon the fact that the concentrations of the radioelements (K, $\mathrm{U}$ and $\mathrm{Th})$ varies measurably and significantly with lithology [28]. Potassium abundance is measured directly as gamma rays energy emitted when ${ }^{40} \mathrm{~K}$ decays to ${ }^{40} \mathrm{Ar}$, whereas uranium and thorium cannot be measured directly. Distinct emission peaks associated with ${ }^{208} \mathrm{Tl}$ and ${ }^{214} \mathrm{Bi}$ are used to calculate the concentration of $\mathrm{Th}$ and $\mathrm{U}$. Therefore, $\mathrm{U}$ and $\mathrm{Th}$ are expressed in equivalent concentrations (eU and eTh) [29]. Uranium distribution actually observed in peraluminous granitoides results from five main phenomena: partial melting, magmatic differentiation, late magmatic processes, hydrothermal and meteoric alterations [30].

Kadabora pluton is characterized by higher concentrations of $\mathrm{Th}, \mathrm{U}$ and $\mathrm{K}$ than in the country rocks. Uranium and thorium are generally enriched in the youngest, most felsic and most potassic members of comagmatic suites of igneous rocks [31]. Thorium is more resistant to environmental leaching processes than uranium. The equivalent thorium contour map (Fig. 4) subdivided Kadabora pluton into three parts; the southern part located SW with lower concentration of about $10 \mathrm{ppm}$, the central part with medium concentration of about $14 \mathrm{ppm}$, and the northern part with higher concentrations of about $20 \mathrm{ppm}$. The central part of the core of the pluton is mainly monzogranite in composition while, the southern and the northern parts are mainly syenogranite exhibiting different Th concentrations. The southern part suffered from leaching of radioelements, while the northern part of the pluton has characteristic features that help in increasing the late magmatic thorium concentrations due to hydrothermal activity. The granitic rocks of Kadabora may be regarded as homogeneous representing crystallization of the granitic magma in one phase of emplacement [13]. So magma differentiation trend follow up is very easy from equivalent thorium distribution map, where the center of the pluton was crystallized first, followed with the outer part of the pluton and at the end pegmatite as late magmatic stage. 


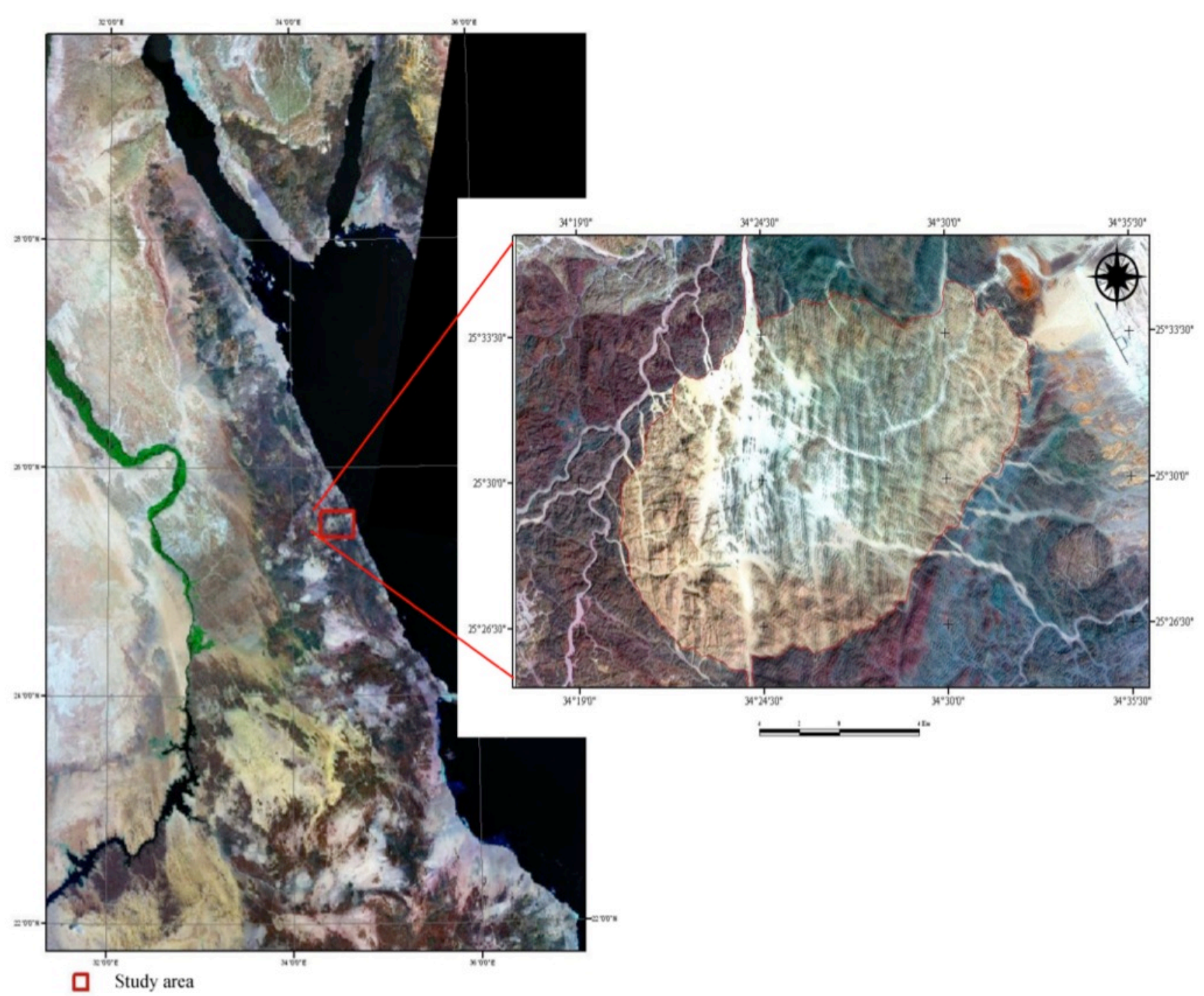

Fig. (2). Location map of Kadabora pluton, central Eastern Desert, Egypt.

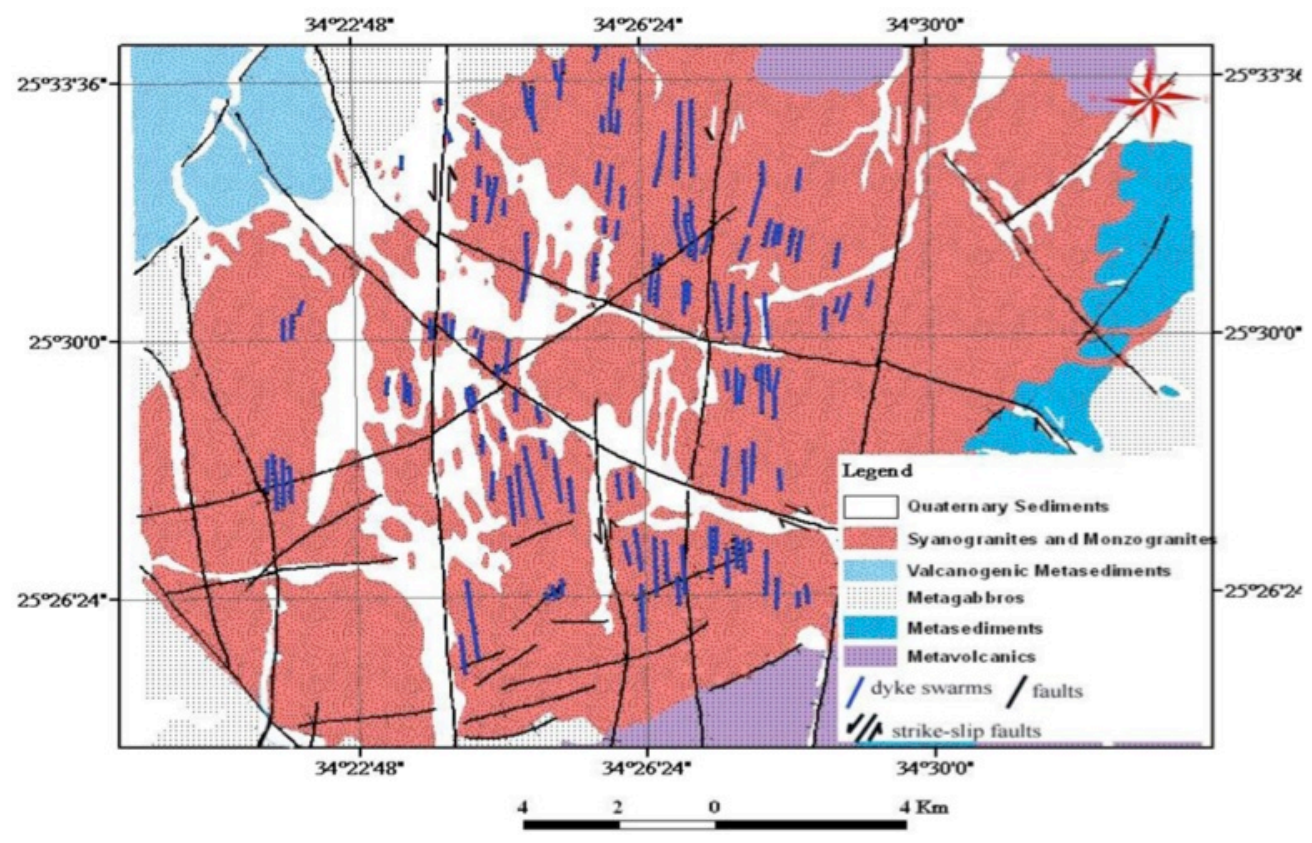

Fig. (3). Modified Geologic map of Kadabora pluton, central Eastern Desert, Egypt (after Ahmed, 2002). 


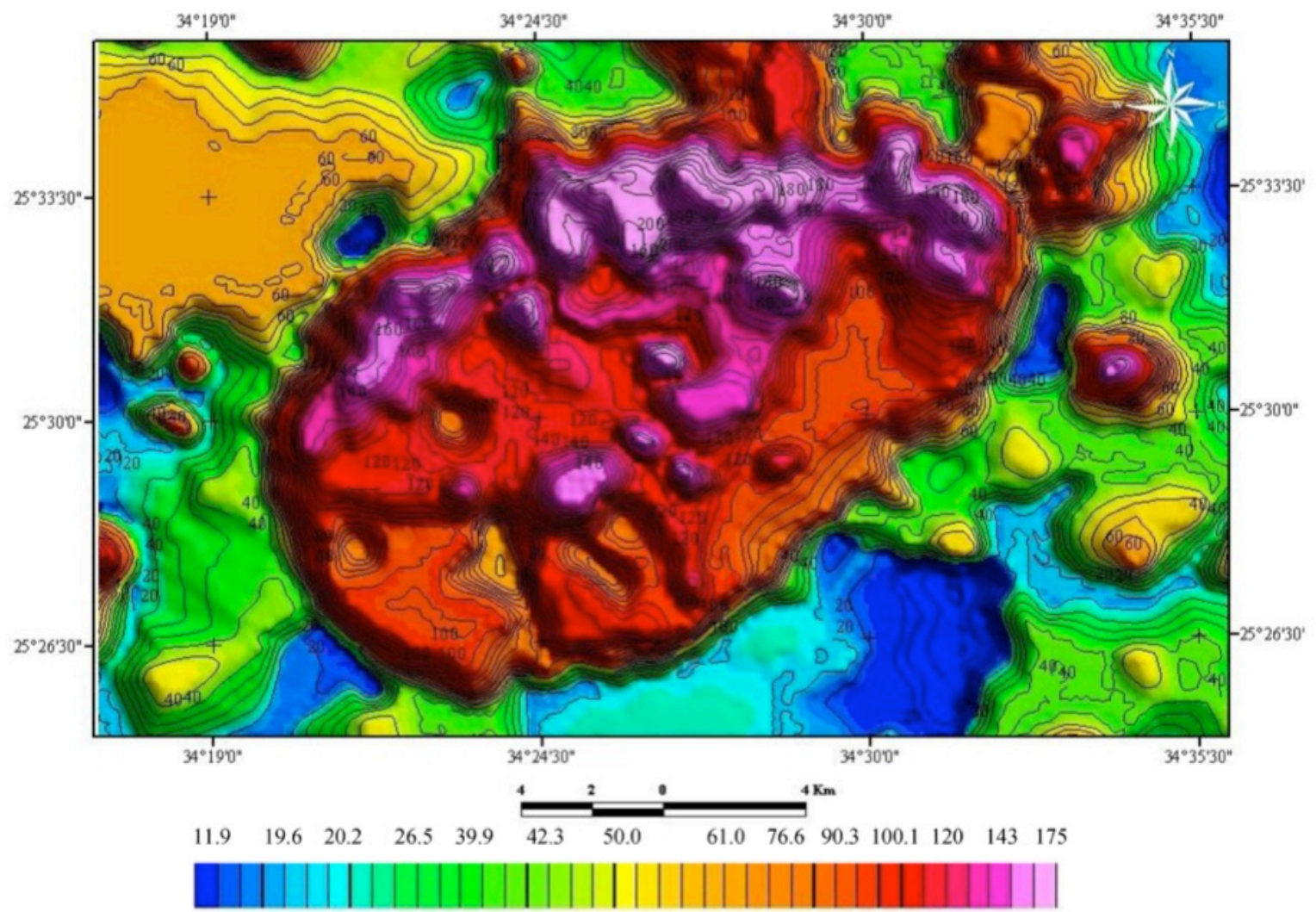

Fig. (4). Shaded relief contour map of equivalent thorium (values in ppm multipled by 10) of Kadabora pluton, central Eastern Desert, Egypt.

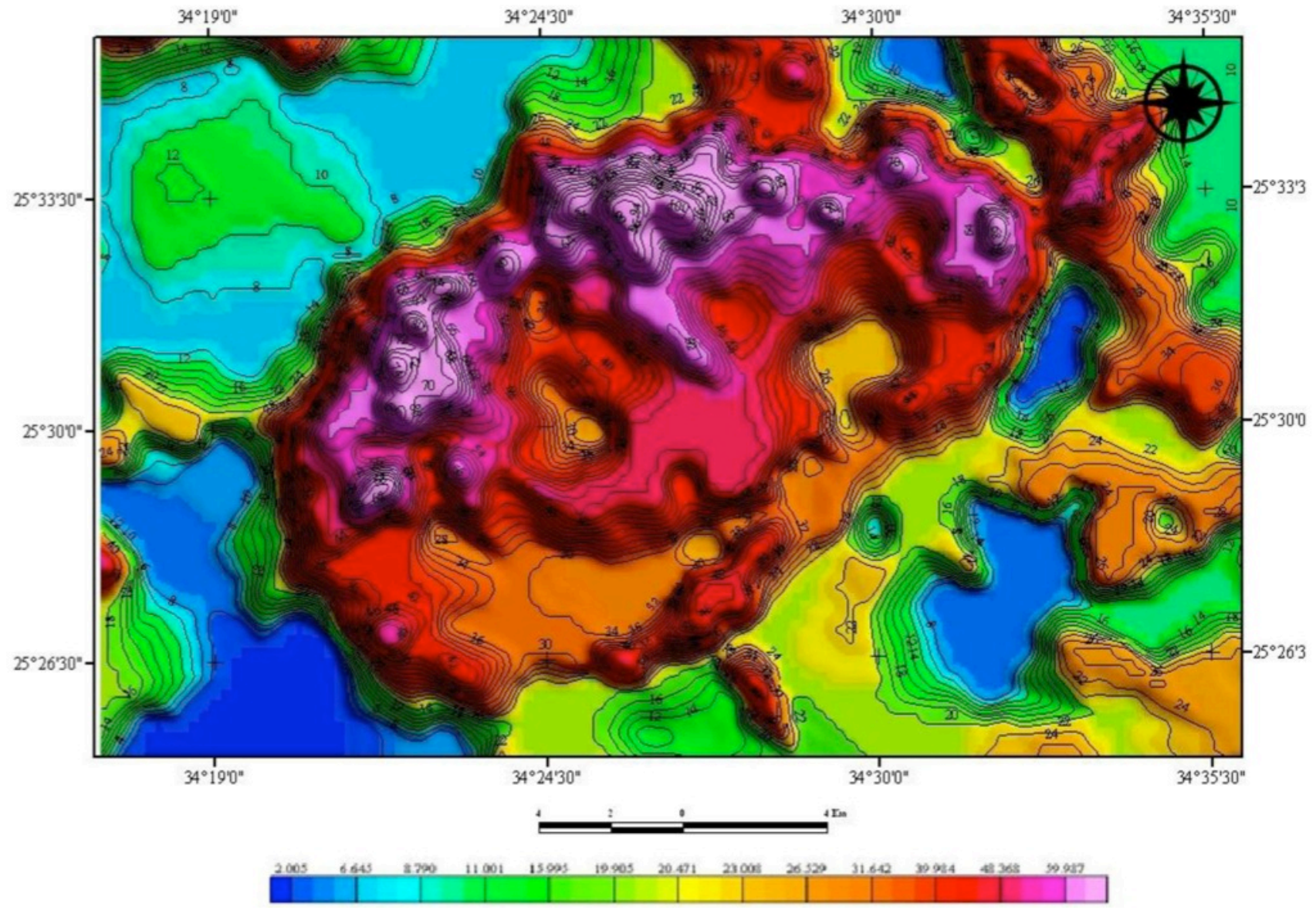

Fig. (5). Shaded relief contour map of equivalent uranium (values in ppm multipled by 10) of Kadabora pluton, central Eastern Desert, Egypt. 
Uranium is a more mobile element than thorium, so if thorium is very good indicator of the magmatic processes, uranium is a good indicator for the post-magmatic alteration processes. On the equivalent uranium (eU) map (Fig. 5), the southern part is increased to the east and envelopes parts of the monzogranite. This means that the southern half of the pluton was subjected to the same conditions, but syenogranite shows more susceptibility to leaching than monzogranite. The $U$ higher values are concentrated mainly in the northern outer parts of the pluton more than in the central and southern parts with maximum value of about 10 ppm. Dyke swarms (Fig. 3) of different composition played different roles in uranium migration, to the east uranium concentrations is very low, where dolerite is the most abundant dike type, probably because they help only in transportation of uranium, while acidic dikes to the center may have focused the mineralization. The area of pegmatites trapped leached uranium mineralization.

An estimate of the original equivalent uranium concentration obtained by dividing equivalent thorium concentration map by 3.5 (Fig. 6) suggests how uranium was originally distributed in the area to compare with the present uranium concentration map (Fig. 5). This comparison suggests that uranium may have been leached from the southern part of the pluton and redistributed northward along joints, faults and wadis. The effect of hydrothermal activity is suggested by eTh/eU map of the northern area (Fig. 7), in which the secondary uranium mineralization is highly concentrated. This area represents the more promising area in Kadabora pluton.

The distribution of potassium is very similar to that of uranium (Fig. 8), except in the part that has less alkalinity in the center of the pluton. Over the whole batholith, both $\mathrm{K}$ and $\mathrm{U}$ increase northwards. The potassium contents range between 2 and 5\% (Fig. 8). Secondary potassic alteration zones in the northern part of the pluton are suggested by low thorium to potassium ratios of about two (Fig. 9).

A ternary radiometry map uranium, thorium and potassium were prepared (Fig. 10) combining uranium as red, thorium as green and potassium as blue. Areas of relatively high uranium concentration are white, areas of pale green correspond to partial uranium enrichment zones, while areas of deep green are uranium probably leaching zones. PCA analysis can be done either on satellite images or on other geo-data sets for geophysical data [32] and [33]. This type of analysis is useful when there are number of data layers, which can be overlain one over another. With the advent of geographic information system, integrated analysis of spatially distributed data can be done easier [34]. A PCA statistical analysis was calculated for the radiometrically determined elements (Fig. 11). PCA analysis for gamma ray spectrometry data can be used as a powerful tool for mapping potential alteration zones in Kadabora granite area were the altered areas are displayed by brightness pixels (Fig. 11).

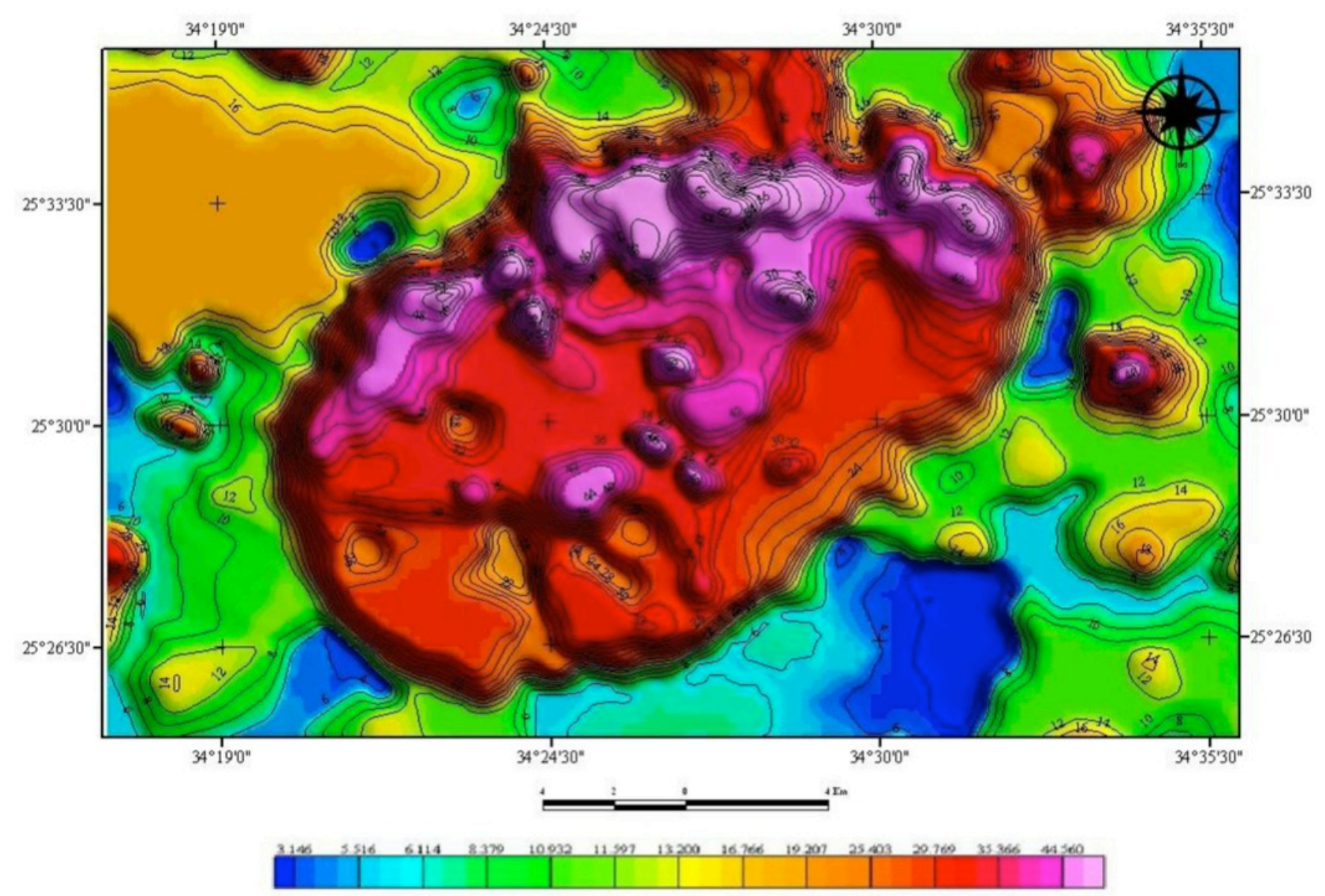

Fig. (6). Shaded relief contour map of original uranium (eTh /3.5) of Kadabora pluton, central Eastern Desert, Egypt. 


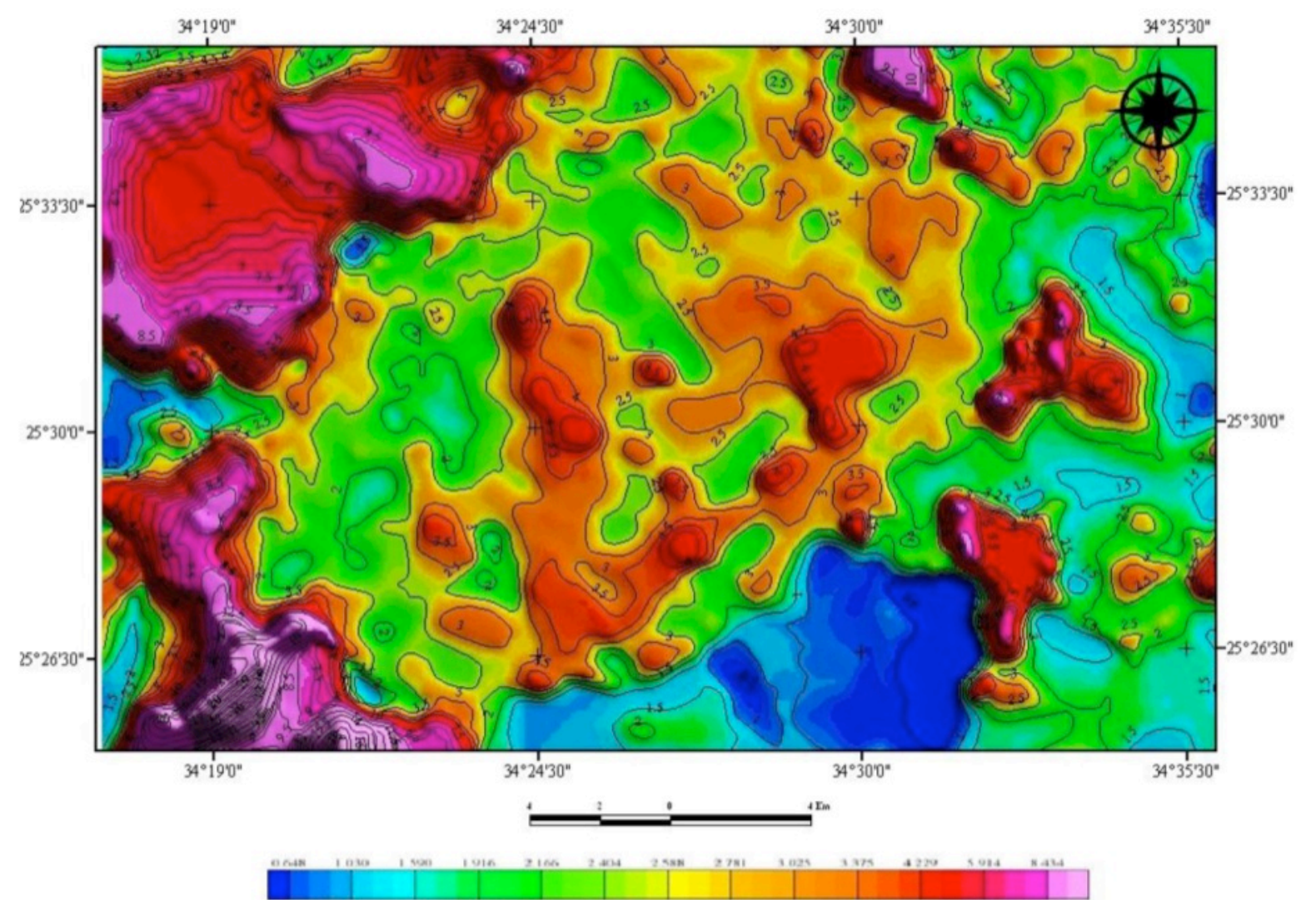

Fig. (7). eTh / eU ratio shaded relief contour map of Kadabora pluton, central Eastern Desert, Egypt.

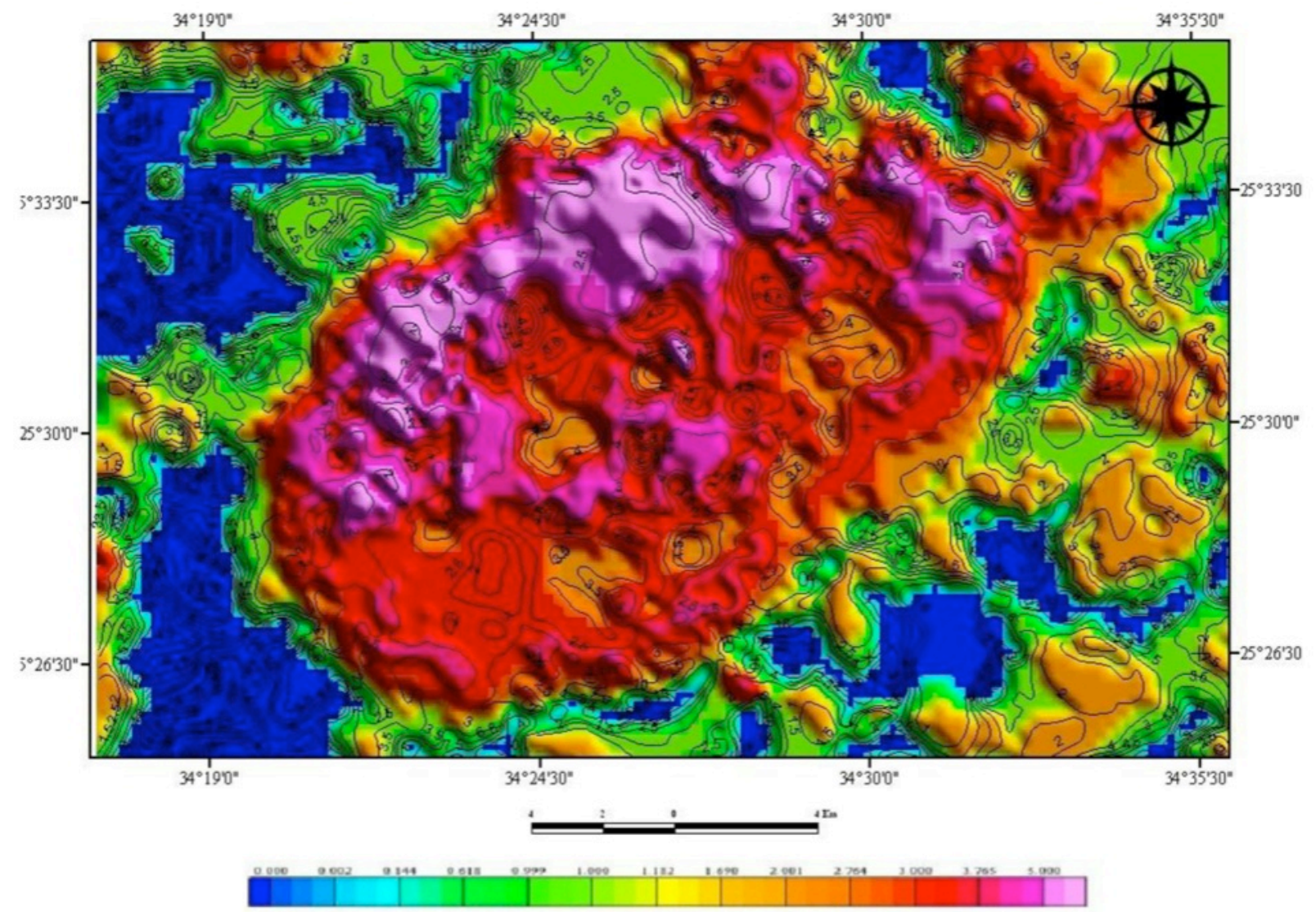

Fig. (8). Potassium distribution contour map (values in percent with a log scale) of Kadabora pluton, central Eastern Desert, Egypt. 


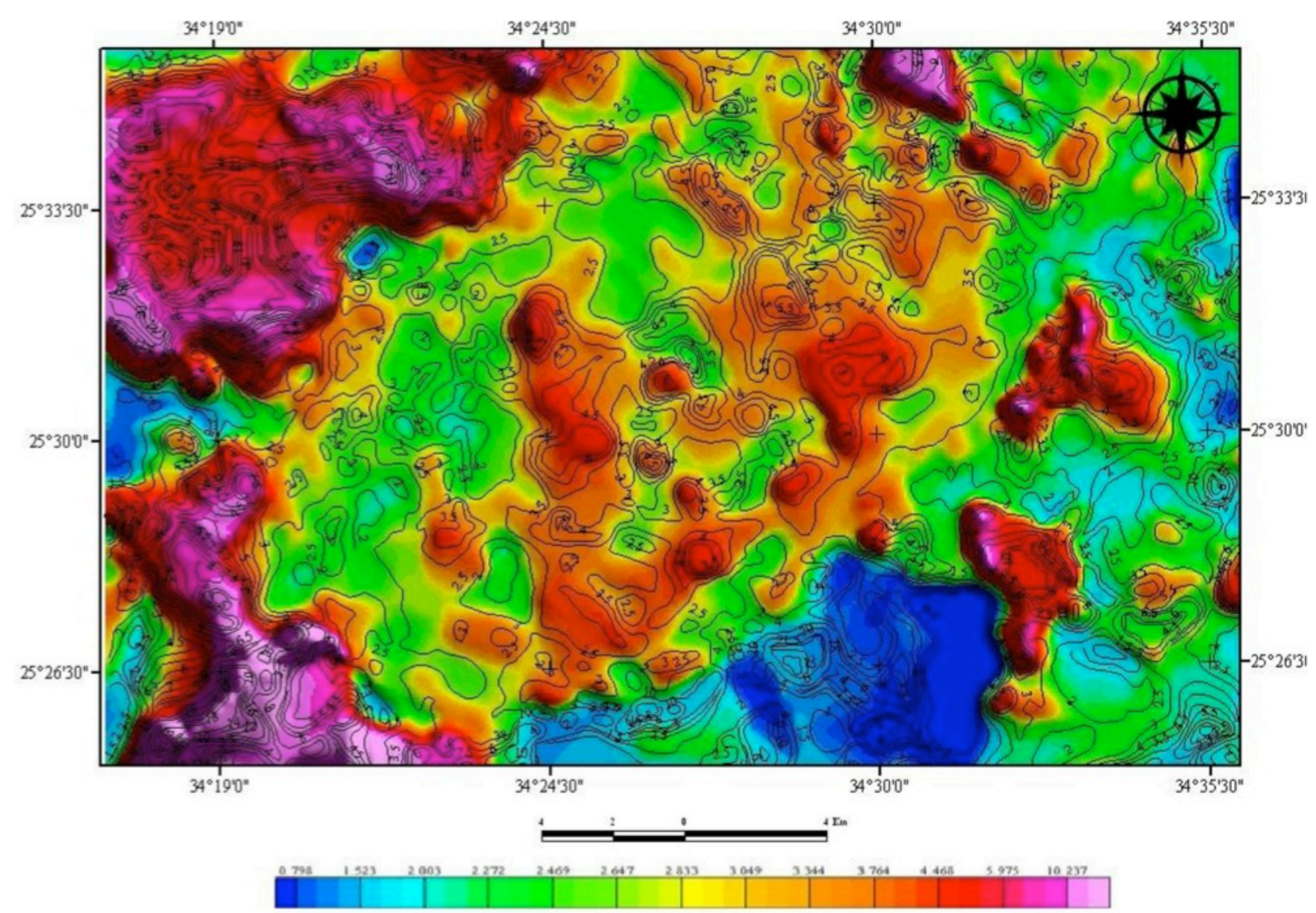

Fig. (9). eTh/K ratio shaded relief contour map of Kadabora pluton, central Eastern Desert, Egypt.

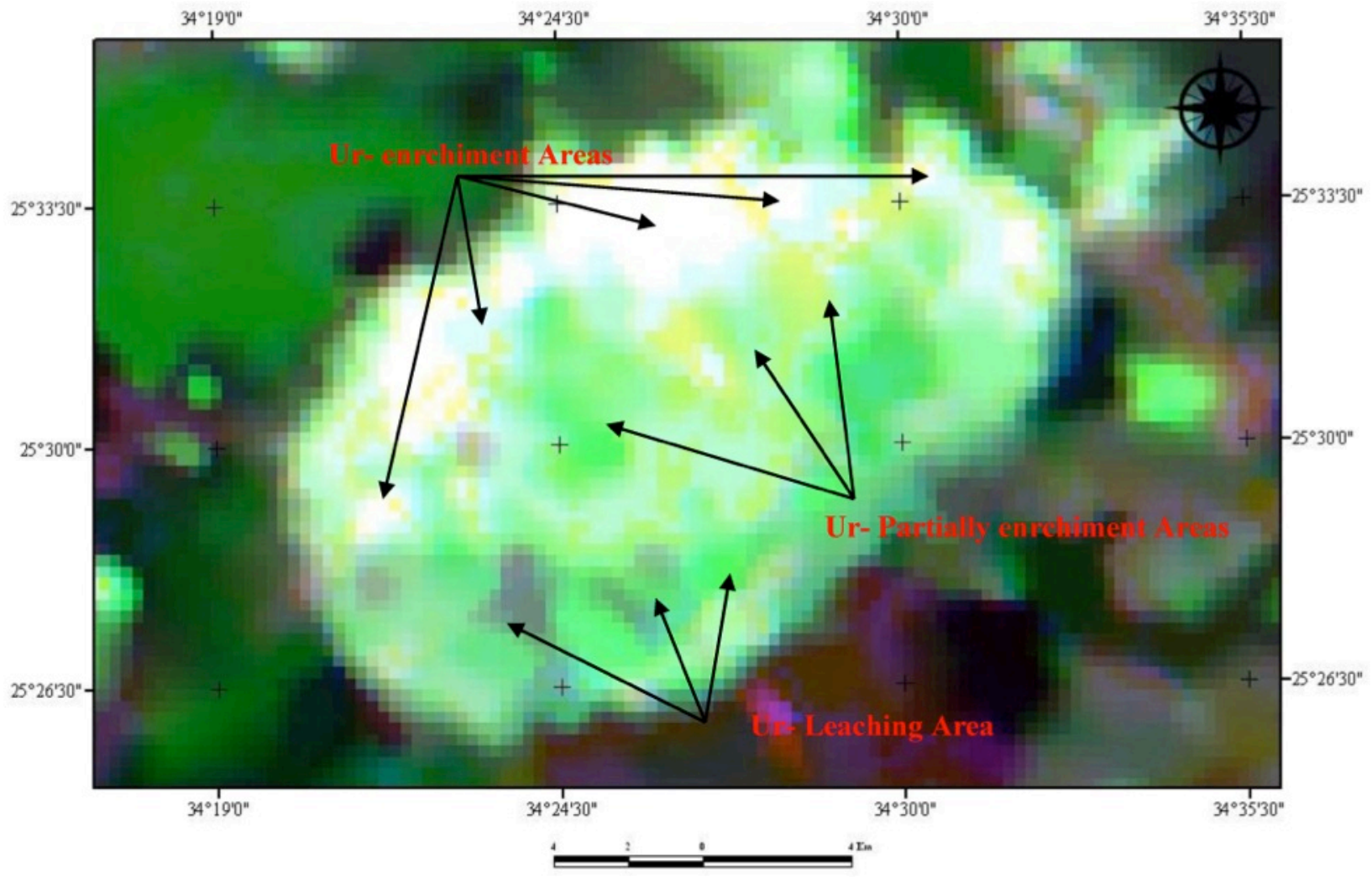

Fig. (10). Ternary map of U, Th, K in RGB for Kadabora pluton, central Eastern Desert, Egypt, U enrichment zones are bright. 


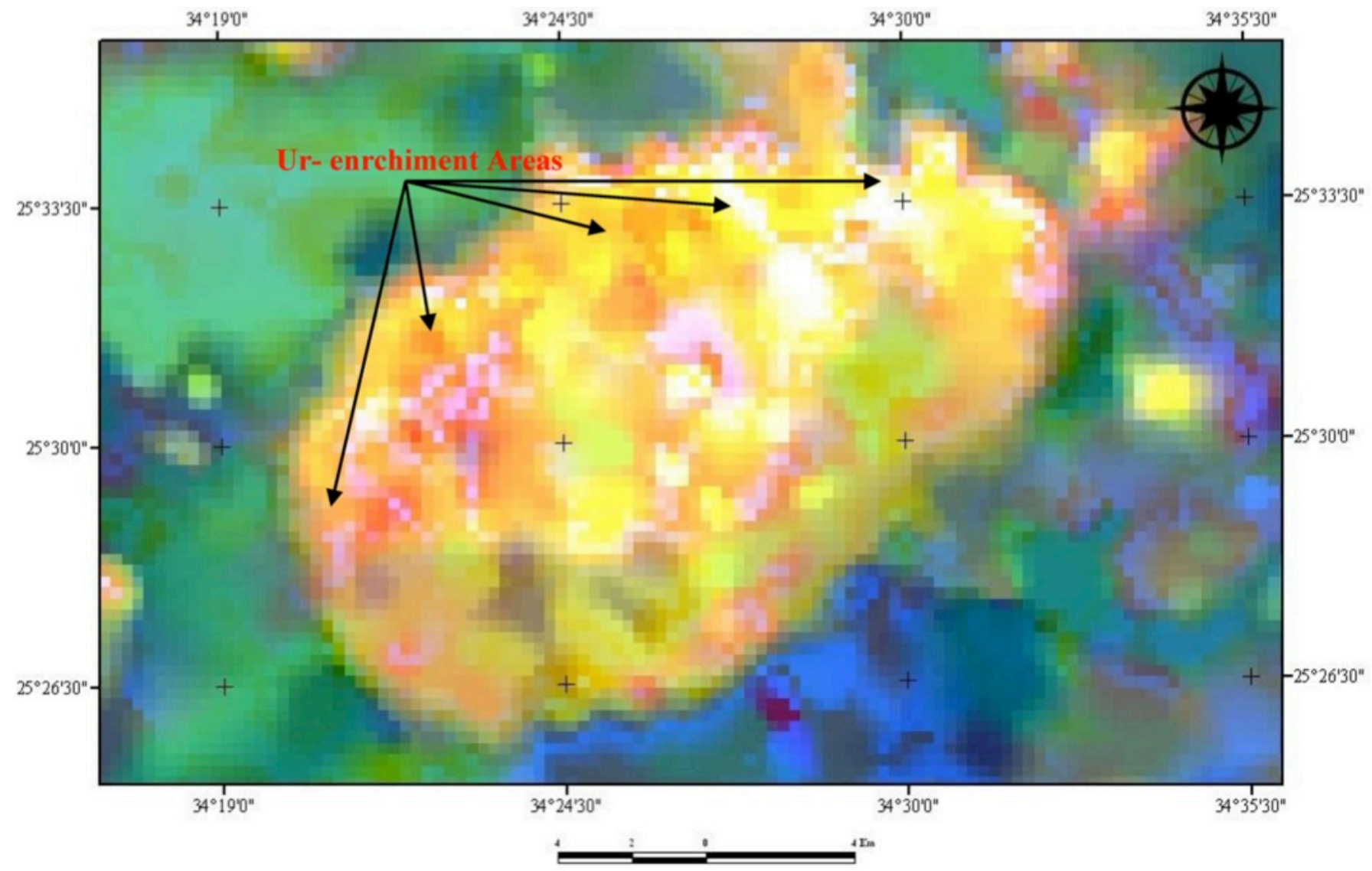

Fig. (11). PCA analysis for ternary radioelement $U, T h, K$, Areas of extensive alteration zones are bright.

\subsection{Landsat ETM ${ }^{+}$Data Analysis and Interpretations}

Landsat Enhanced Thematic Mapper plus (ETM+) data $(173 / 043$ path/row) covering Kadabora area was used to assist in mapping and identifying the uranium-bearing zones to distinguish the variations in the dominant mineralogy of the various types, including variations of clays, white micas, hydroxides and ferric minerals that have resulted from alteration. Multispectral bands $(60,30 \mathrm{~m}$ pixel size $)$ and panchromatic band ( $15 \mathrm{~m}$ pixel size) were merged together to resize the image data into $15 \mathrm{~m}$ resolution. Various imageprocessing techniques (FCC, band ratio, PCA, intensity-huesaturation (IHS) transformation, and least square fit (Ls-Fit) method) were applied. The main target of image data processing is to identify, isolate and enhance the high anomalous concentrations of altered hydroxides and ferric minerals, which are used as indicators of buried uranium mineralization and thus favorable areas for further uranium exploration.

An image of bands of 754 in RGB channels was used to distinguish between three uranium-bearing zones associated with the three granitic phases in Kadabora area [21] depending on their spectral reflectance curves (Fig. 12). The combination 7:5:4 for R:G:B are transformed into IHS images (Fig. 13) respectively to distinguish between the three uranium bearing zones in study area.

Two main common ratio techniques were applied as a reference guide for mapping the hydroxide and iron oxide alteration zones. 5/7 ratio image is used to detect the higher clay minerals and sheet silicates of $\mathrm{Al}-\mathrm{OH}-$ and $\mathrm{Mg}-\mathrm{OH}-$ bearing minerals in hydroxide alteration zone. On the other hand, 3/1 ratio image is used for iron oxide bearing minerals which contain $\mathrm{Fe}-\mathrm{OH}$ bearing minerals in the gossan zone. As the bright image signature values are the major index for higher content of target alteration zones while the dark values are correspondent to poor ones $[35,36]$ and those ratio images was assigned to black and white image transform to better distinguish between altered and country rocks (Figs. 14a, b).

PCA statistical multivariate analysis is used for reducing dimensionality of correlated multispectral band data. Two selected PCA layers were produced from analysis of six TM bands analysis using Crosta technique [37] to highlight the hydroxyl-bearing (clay) minerals, and iron-oxide minerals. PC4 and PC3 are used because of the spectral response of those minerals in TM4 and TM3 bands (TM4 shows high reflectance response from hydroxyl alteration zones and TM3 show high reflectance response from iron oxides zones). Both images are displayed in color and show result as same as image ratios (Fig. 15a, b).

LS-Fit (linear band prediction) was used as an effective tool to assure the results obtained from ratios and PCA. LSFit performs a linear band prediction using a least squares fitting technique. It can be used to find regions of anomalous spectral response (e.g. altered clay minerals, iron oxides zones) in a data set. It calculates the covariance of the input 


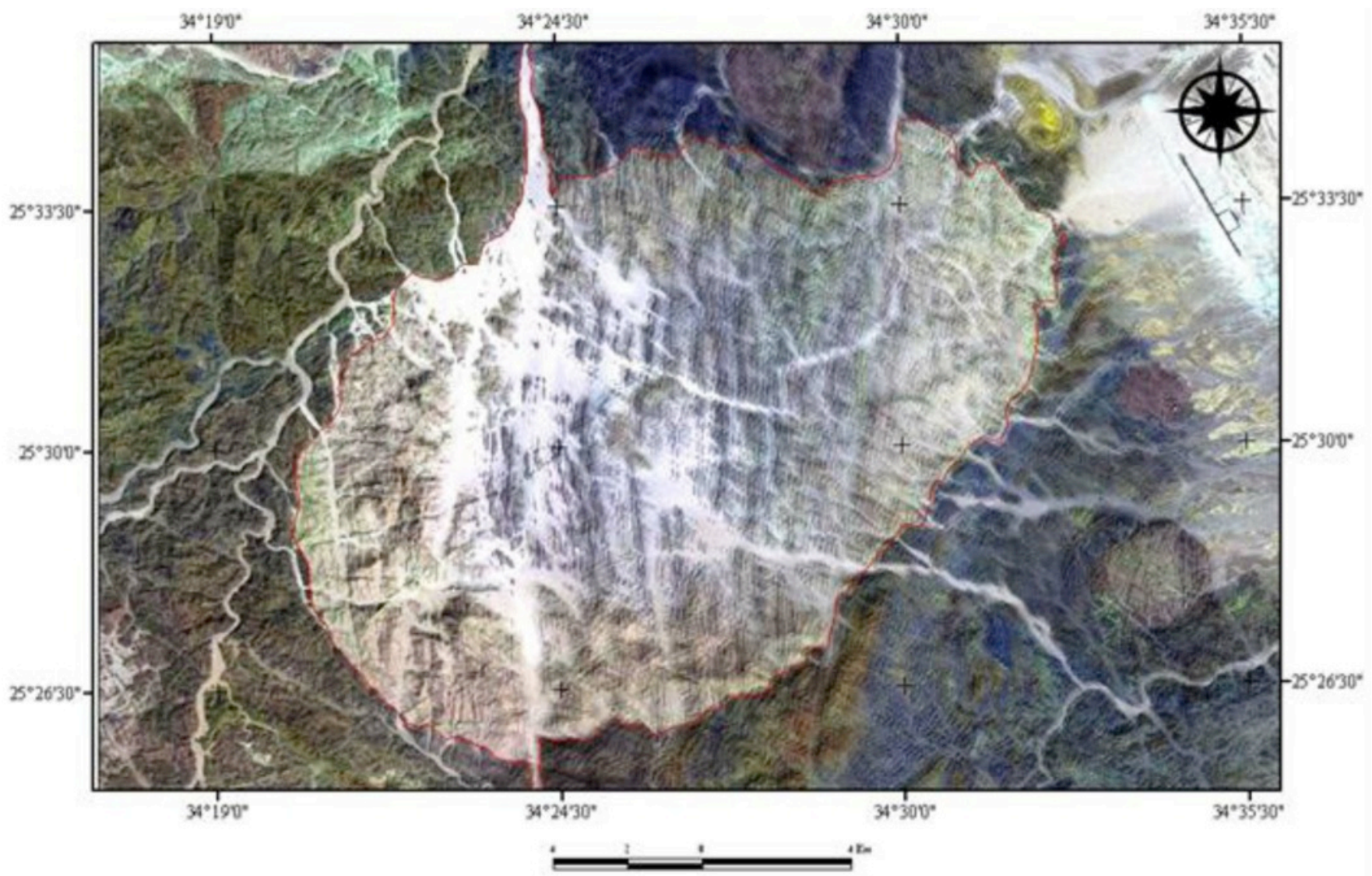

Fig. (12). ETM+ image 754 in RGB of Kadabora pluton, central Eastern Desert, Egypt.

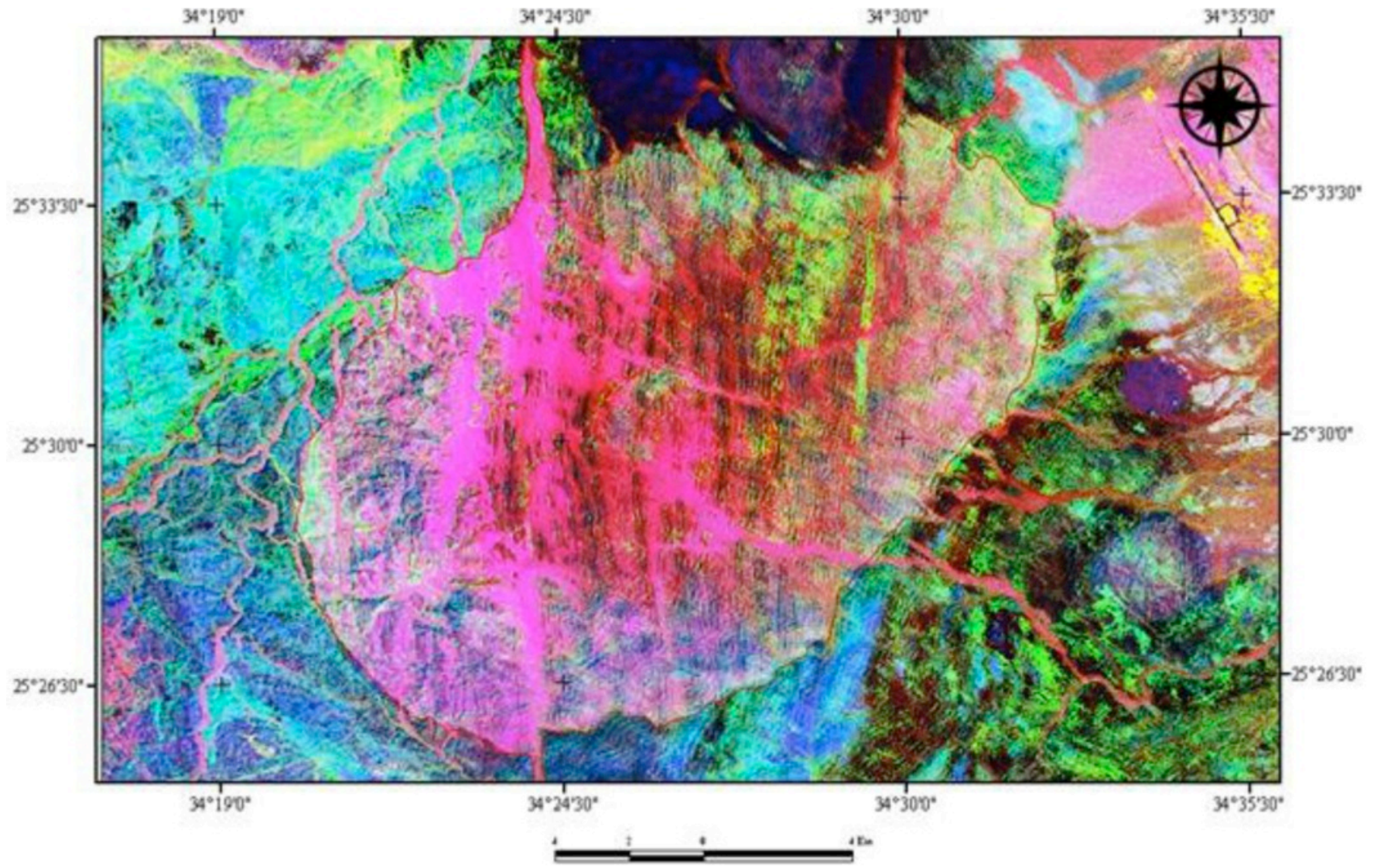

Fig. (13). IHS transformed image of bands 754 of Kadabora pluton, central Eastern Desert, Egypt. 


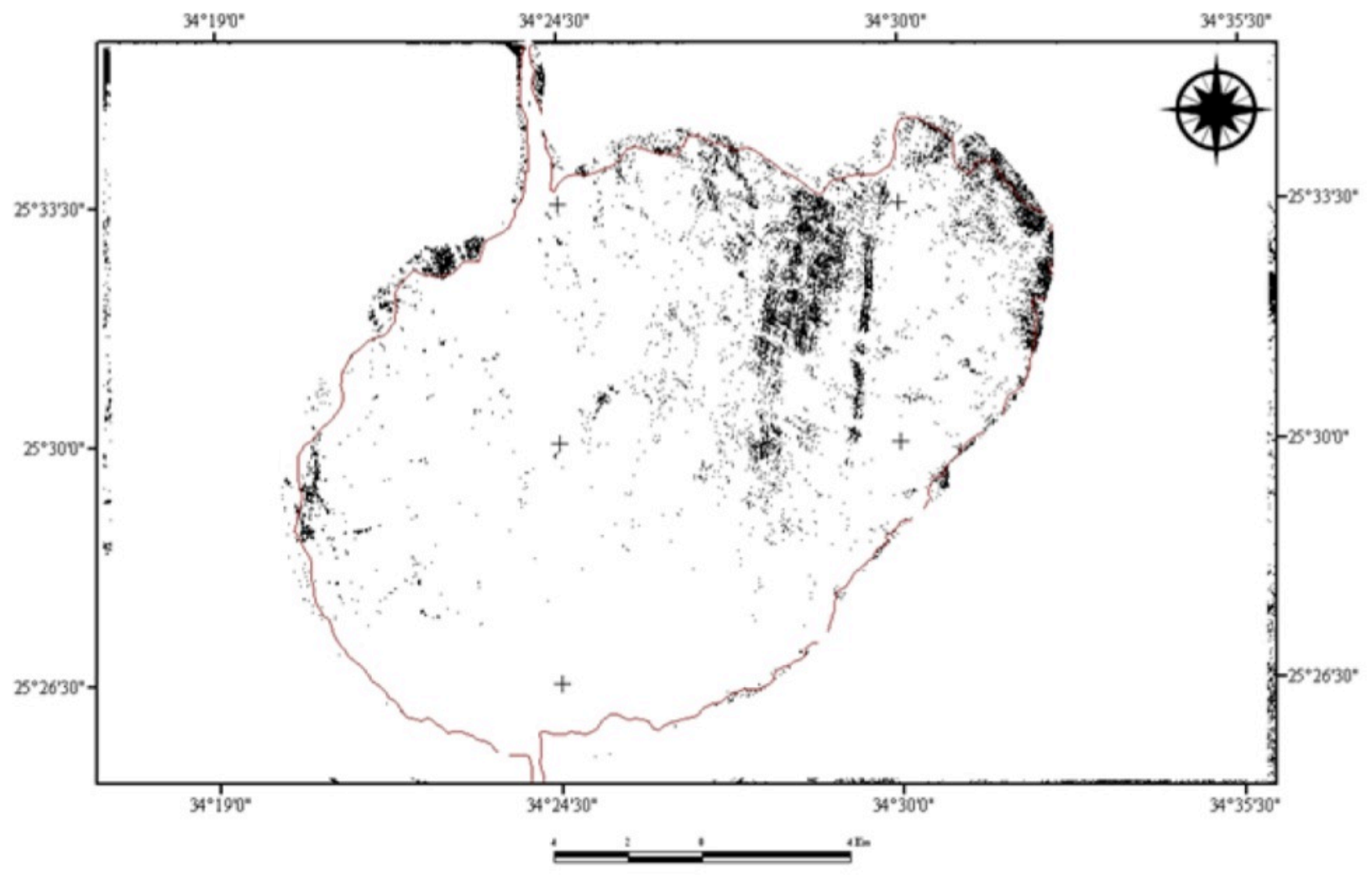

d

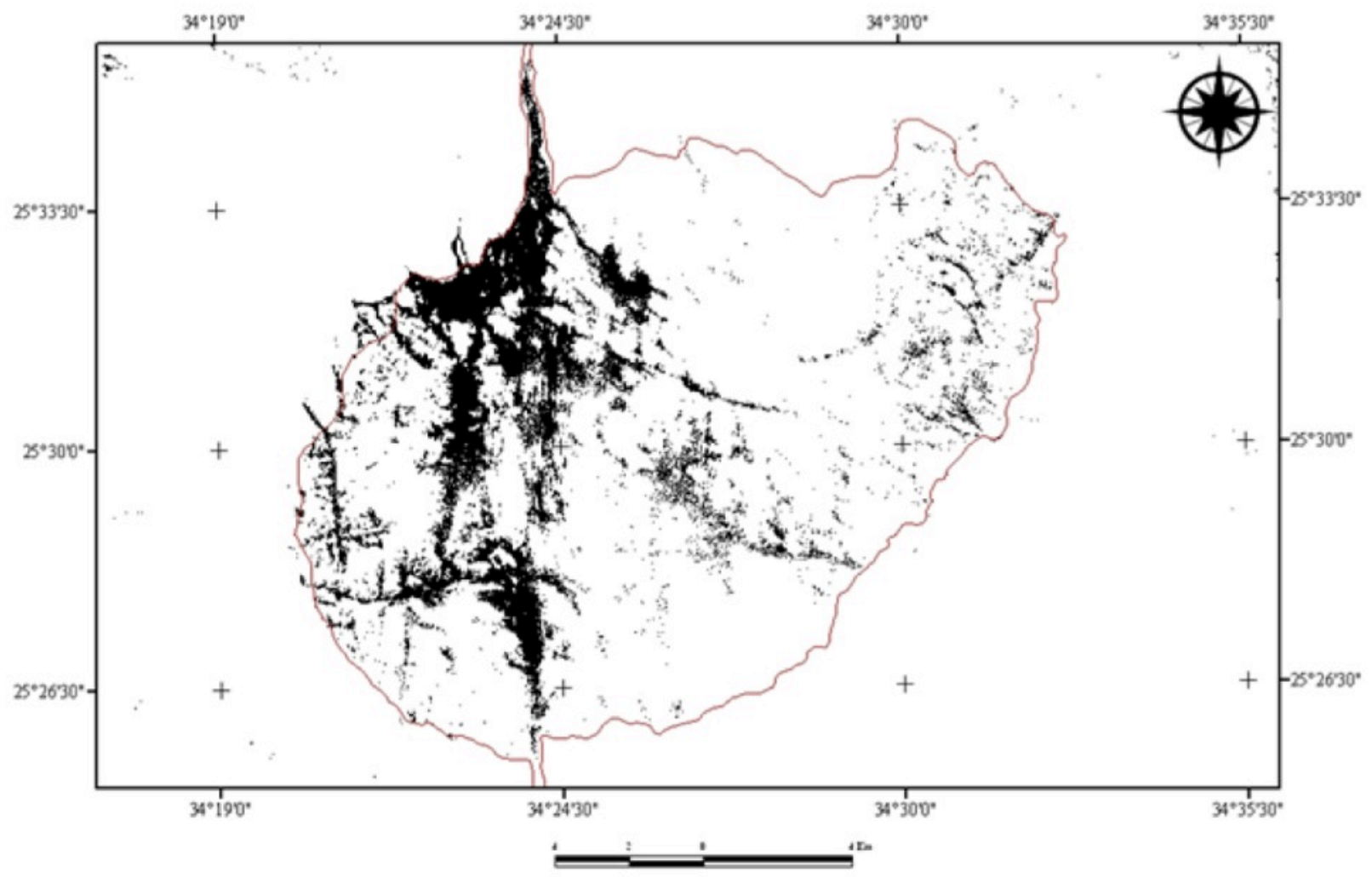

b

Fig. (14). (a, b) Band ratio images 5/7 and 3/1 respectively in black and white assignement, Black areas correspond to higher hydroxide alterations, and black areas in $\mathbf{b}$ show the iron oxide zones. It is clear that both alteration zones follow the general trends of fractures and wadis in Kadabora area. 


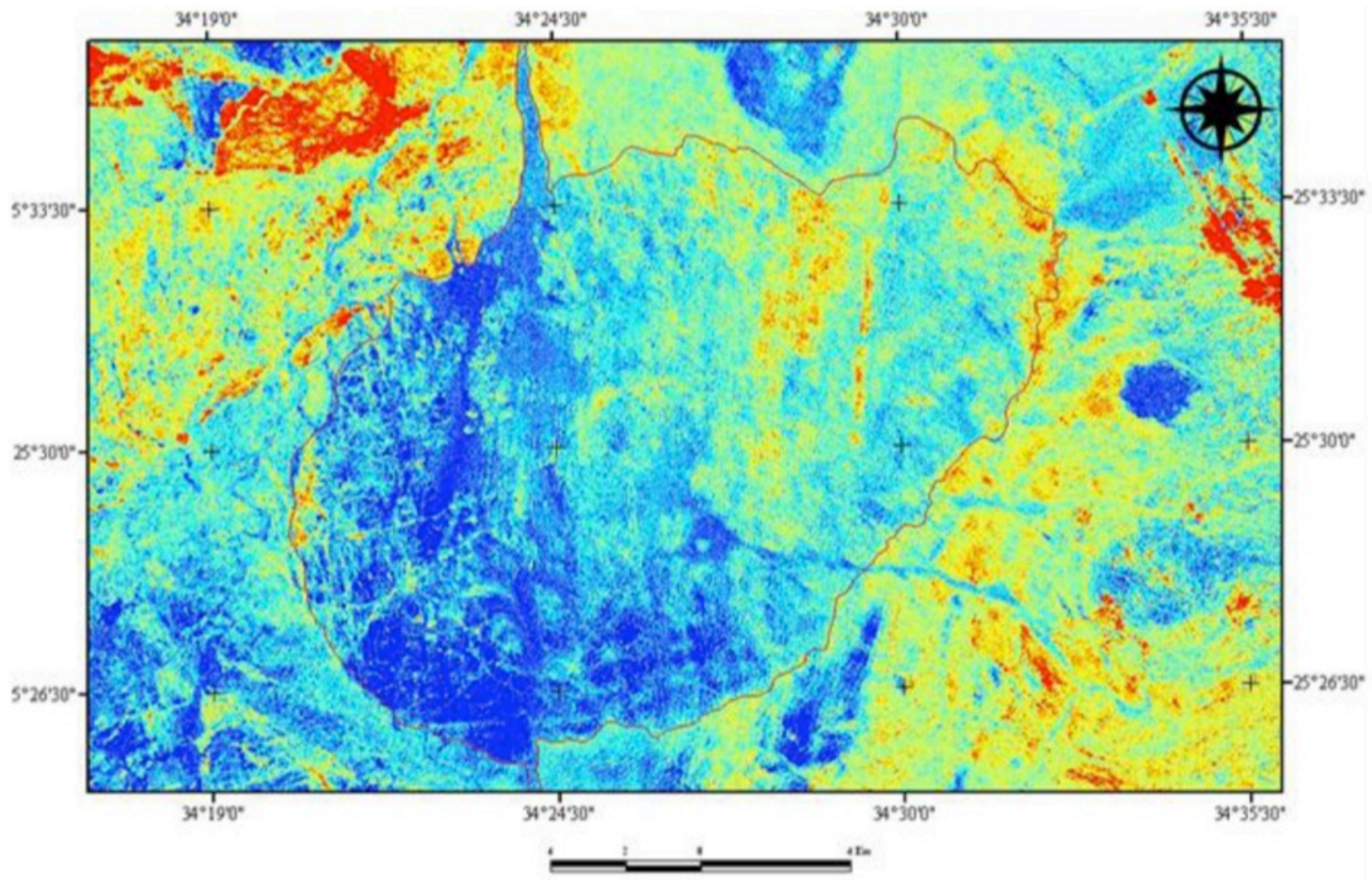

a

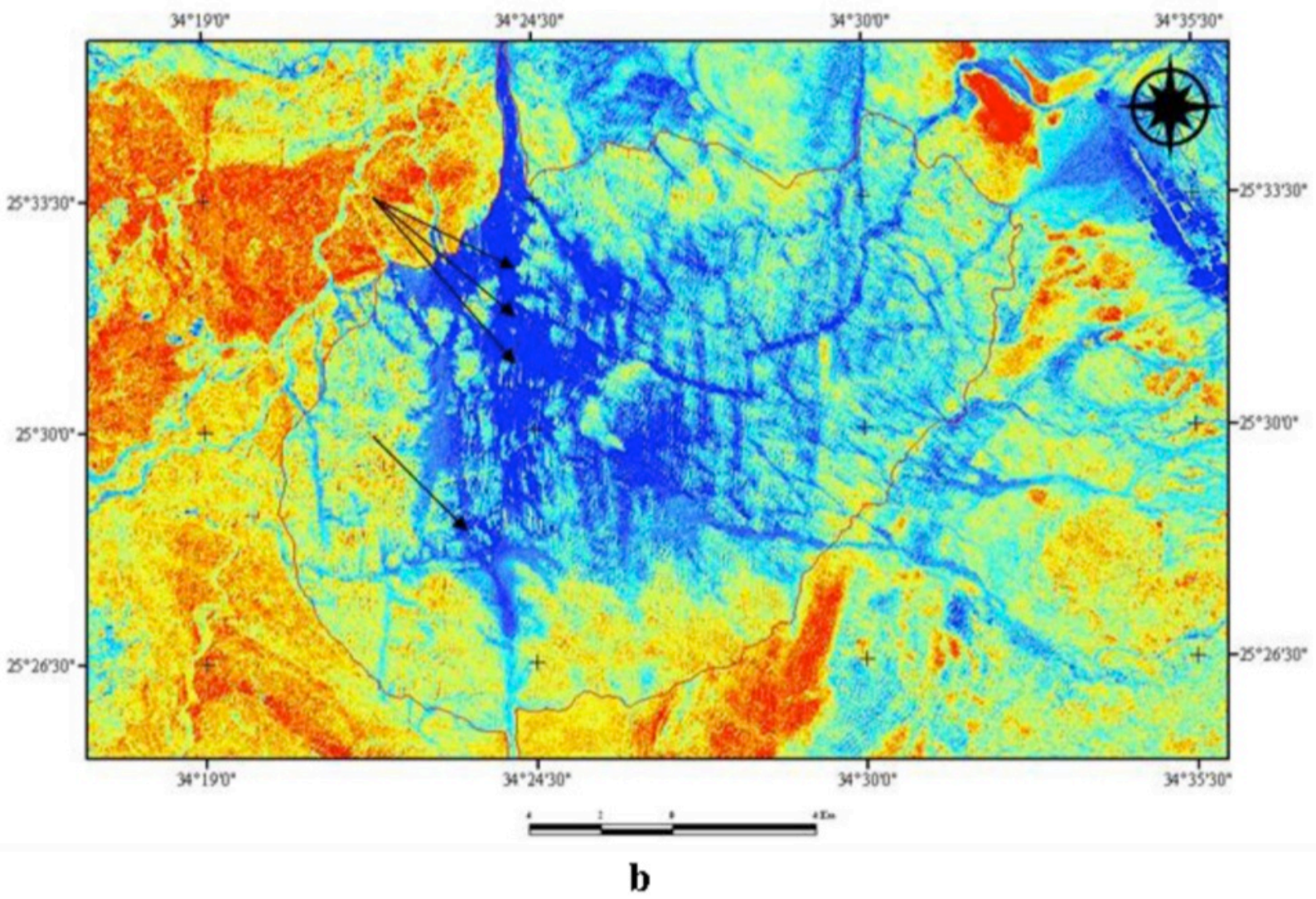

Fig. (15). (a, b) PCA images PC4 and PC3, arrows indicate the high concentration of alteration zones bearing minerals. 


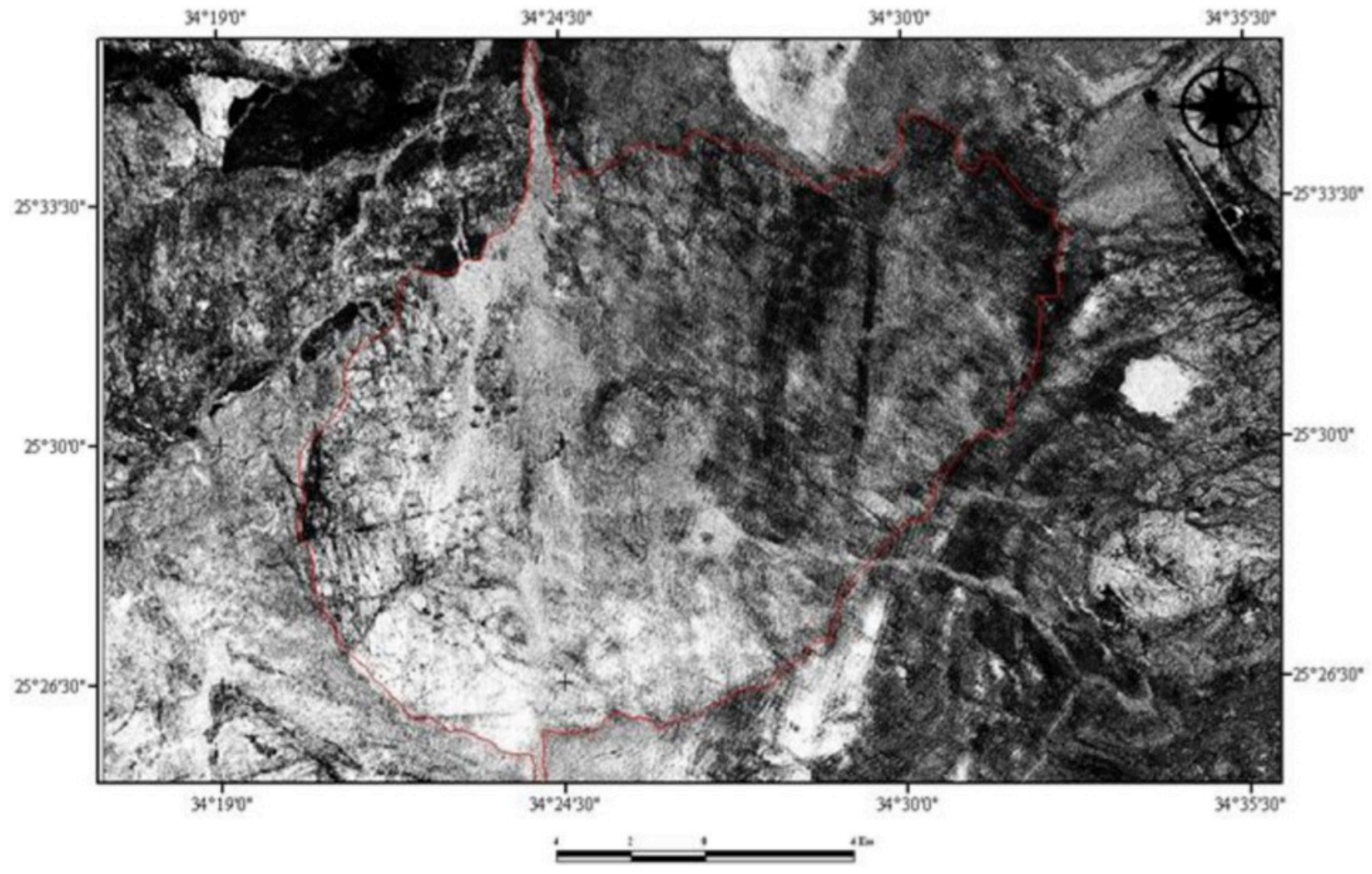

$\mathbf{a}$

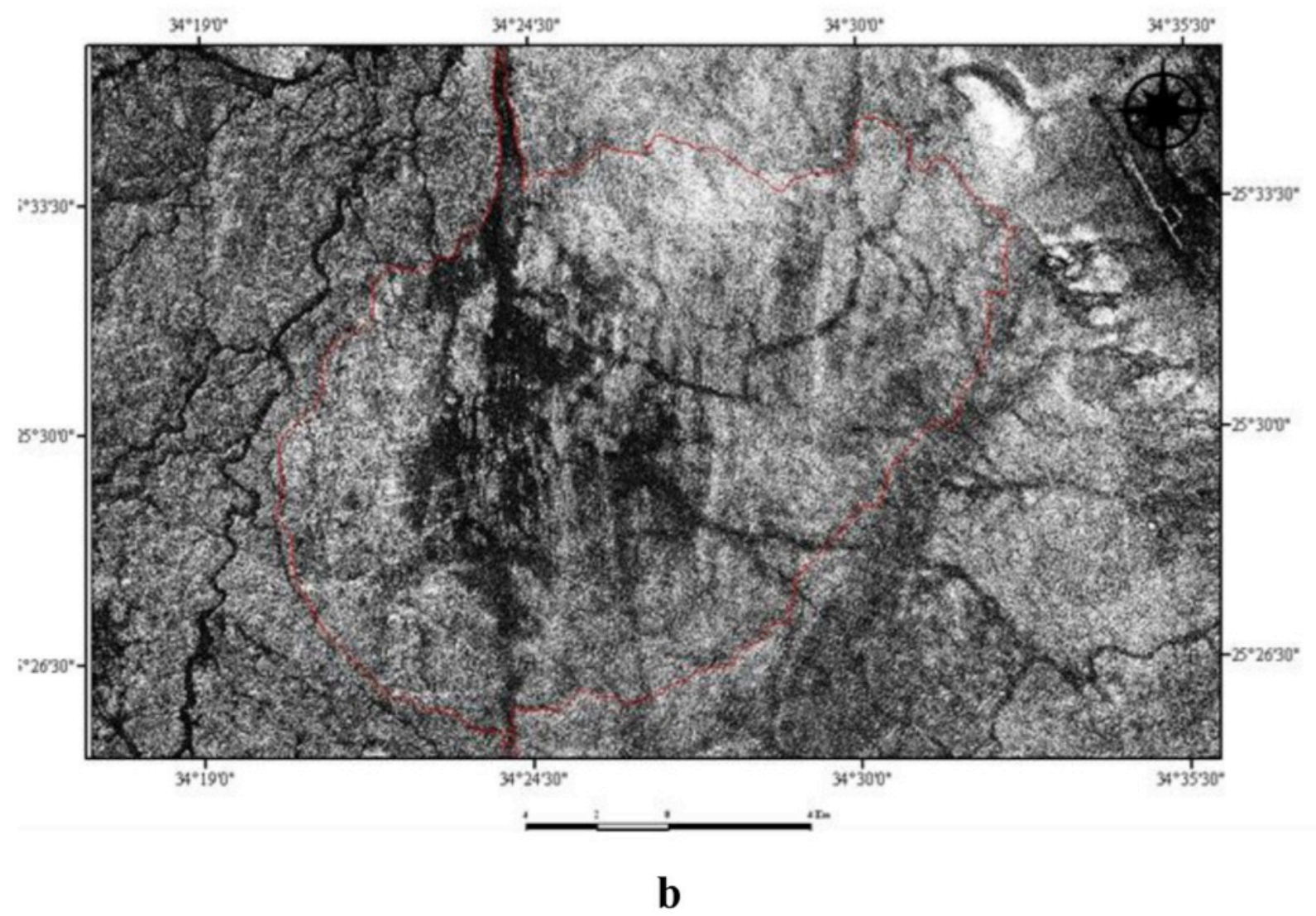

Fig. (16). (a, b) LS-Fit images of band 7 and band 1 residuals, the black pixels correspond to highly altered zones. 


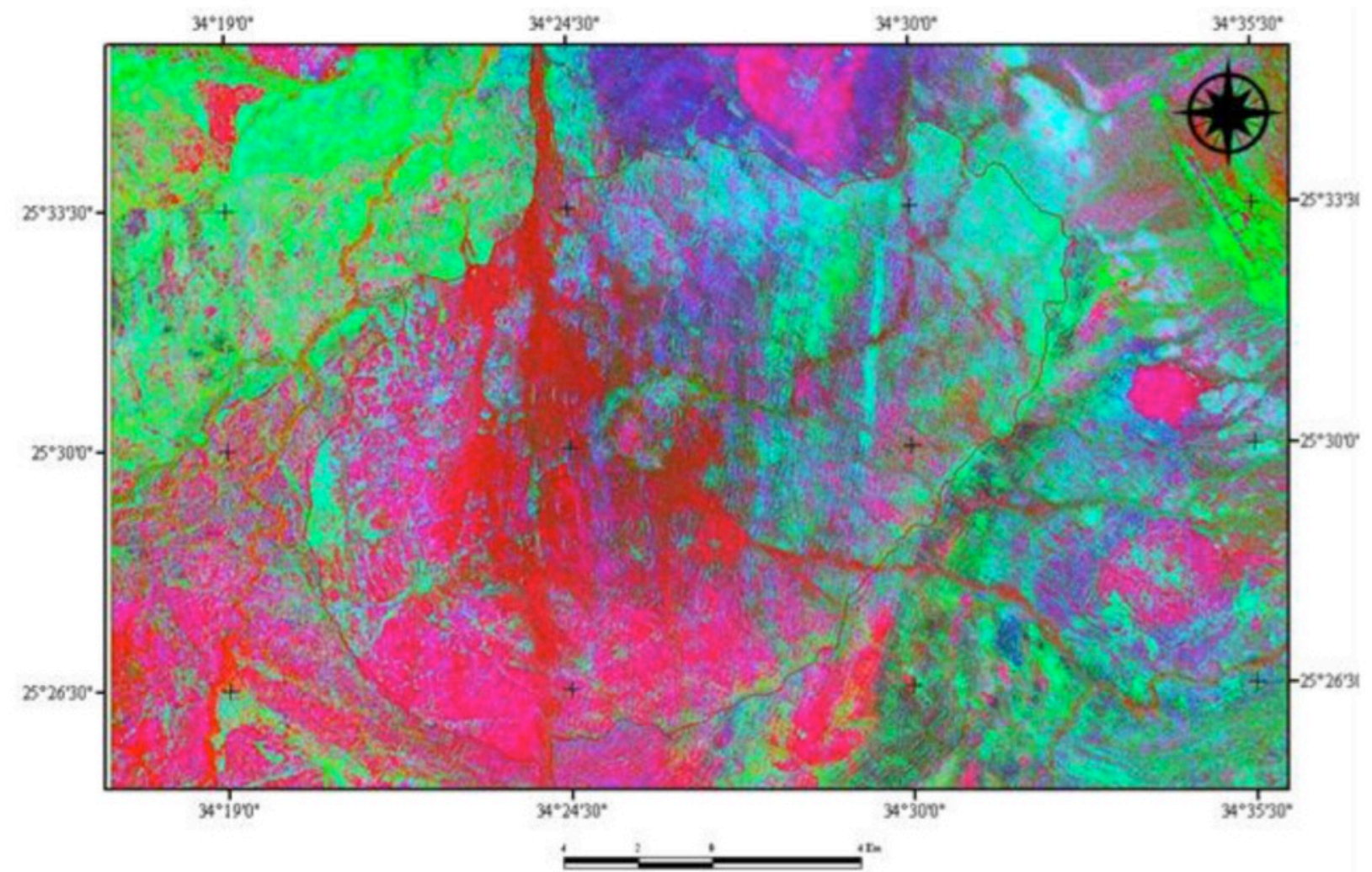

Fig. (17). LS-Fit Image of residuals 7,5,1 in RGB, hydroxyl zones are appeared by cyan, and greenish colors, while red break colors correspond to iron oxide zones.

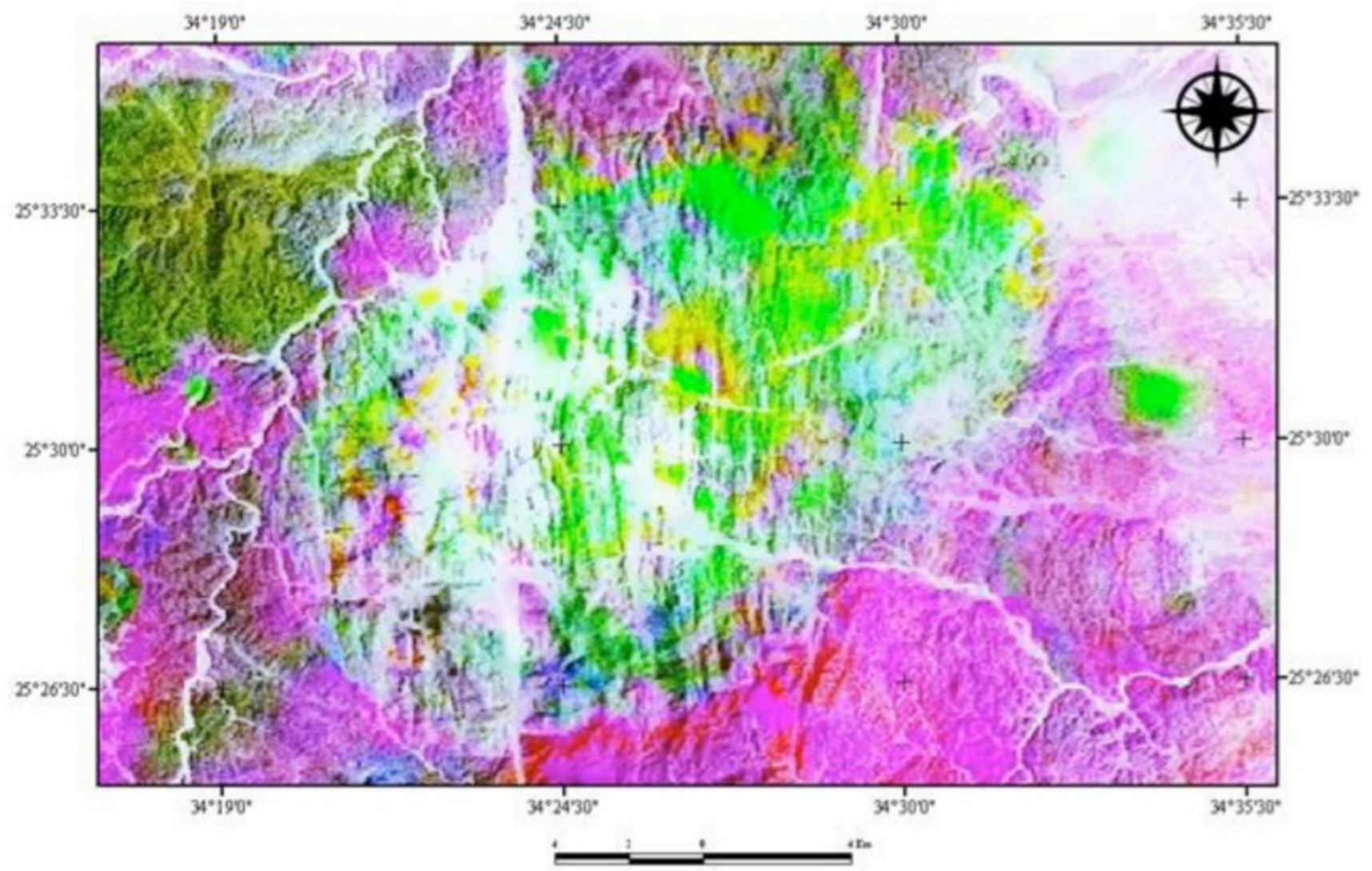

Fig. (18). Radiosensing map of ETM+ band 7 overlain with uranium, thorium, and potassium images. Yellowish green patches correspond to highly radioactive zones. 
data and uses it to predict the selected band as a linear combination of the predictor bands. The difference (residual) between the actual band and the modeled band is calculated and output as a RGB image combinations. Pixels with a large residual (positive and negative) indicate the presence of a feature not predicted (that is an absorption band). The predicted band can be calculated using existing statistics or from new statistics. Here the visible band 1 is used to calculate the residuals for the IR bands and the IR band 7 is used to calculate the residuals of $1,2,3$ visible [38]. Both residual bands of 1, 7 are gray scale images used to better mapping for hydroxyl and iron oxide zones (Fig. 16a, b). LS-Fit combinations of residuals 7, 5, 1 are stacked together in RGB (Fig. 17) to indicate in colors the areas of extensive alterations. Further and additional processing used the integrations between radio images of uranium, thorium, and potassium raster data with ETM+ band 7 to produce a radiosensing map (Fig. 18). This map is an effective tool for mapping the high potential radiometric zones with brightness zones.

\section{CONCLUSIONS}

The integration between airborne radiometric and ETM+ datasets revealed a powerful guide for exploring the uranium mineralization in the Kadabora granites. Also the construction of alteration maps in concise with structural lineament led to delineate favorable sites for uranium mineralization in Kadabora granites. From the dataset analysis, the syenogranites are not only enriched in magmatic radioelements, but they have the ability to host secondary mineralization, and show very high response to leaching processes than other rocks like monzogranite. Kadabora pluton can easily be subdivided into three parts the southern part with U-leaching, the central part with partly Uenrichment and the northern part with extensive Uenrichment. Pegmatite bodies, especially mineralized type are located in the outer part of the pluton. PCA analysis is applied for the stacked airborne radio maps and the resulted PC image shows brightness values related to areas of high alteration zones. Different image processing techniques were used to better distinguish between Kadabora three uranium parts. Moreover, combination between TM7 and radiomaps shows the favorable site for secondary uranium enrichment. It indicated from detailed remote sensing and radiometric work that dike swarms help in radioelements redistribution after remobilization, doleritic dikes to the east act as a seal in uranium migration, while acidic dikes to the center trapped the mineralization. Fractures and faults with more or less north-south direction help in hydrothermal solutions circulation especially in the northern parts and controlled their redistribution.

\section{CONFLICT OF INTEREST}

The authors declare that there are no conflicts of interest.

\section{ACKNOWLEDGEMENTS}

Declared none.

\section{REFERENCES}

[1] Johnson PR, Stewart ICF. Magnetically inferred basement structure in central Saudi Arabia. Tectonophysics 1995; 245: 37-52.

[2] Stern RJ, Hedge, CE. Geochronologic constraints on late Precambrian crustal evolution in the Eastern Desert of Egypt. Am J Sci 1985; 285: 97-127.

[3] Pavlidou S, Koroneos A, Papastefanou C, Christofides G, Stoulos S, Vavelides M. Natural radioactivity of granites used as building materials. J Environ Radioact 2006; 8: 1-13.

[4] Rogers JW. Inferred composition of early Archaean crust and variation in crustal composition through time, In: Windley BF, Naqvi SM on eds., Achaean geochemistry (Developments in Precambrian Geology, v. 1: Amsterdam. Elsevier 1978; pp. 25-39.

[5] Abu Dief A. Geology of uranium mineralization in El Missikat, Qena-Safaga road, Eastern Desert, Egypt. M.Sc. Thesis, Al-Azhar Univ., Cairo University 1985.

[6] Ibrahim ME. Geologic and radiometric studies on Um Ara granite pluton, south East Aswan, Egypt. M.Sc. Thesis Mansoura University 1986.

[7] Roz EM. Geology and uranium mineralization of Gabal Gattar area, north Eastern Desert, Egypt, M.Sc. Thesis, Faculty of Science., Al Azhar University, Cairo 1994.

[8] Assaf HS, Shalaby MH, Ibrahim ME, Rashed MA. Ground Radiometric Survey, Shalatin-Halaib Area, Southeastern Desert, Egypt, Internal Report, Nuclear Materials Authority, Egypt (unpublished) 1996.

[9] Bakhit FS, El Kassas IA. Distribution and statistical analysis of radioactivity of the basement rocks in Wadi Atalla-El Missikat area and correlation with the surrounding areas, Central Eastern Desert, Egypt. Ann Geol Surv Egypt 1992; (XVIII): 393-407.

[10] Amin MS. Geology and mineral deposits of Umm El Rus sheet. Geol Surv Egypt 1955; 24-51.

[11] Sabet AH. Geology and mineral deposits of Gabal EI-Sibai area, Red Sea hills, Egypt. Ph. Thesis, Leiden State University, The Netherlands 1961.

[12] Sayyah TA, Hashad AH, Ibrahim AM, Attawiya MY. Contribution to geochemistry of some pink granites, central Eastern Desert. Egypt J Geol 1973; (17): 57-69.

[13] Kabesh ML, Hilmy ME, Salem AKA. Behavior of major elements in the granitic rocks of Kadabora Pluton, Eastern Desert, Egypt. Acta Mineral Petrogr Szeged 1980; (XXIV/2): 245-56.

[14] Kabesh ML, Salem AK, Hilmy ME, El-Nashar ER. Some petrochemical characters of Samadai Granitic Complex, South Eastern Desert, Egypt. Acta Min Pet Szeged 1981; 15(1): 85-96.

[15] Rogers JW, Greenberg JK. Summary of recent work on Egyptian younger granites. Ann Geol Surv Egypt 1983; (13): 185-91.

[16] El-Mahallawi MM, Molnar ZS. REE Geochemistry of the Post Granite Dykes of Gabal Kadabora Area, central Eastern Desert, Egypt, Egypt. Mineralogist 1994; (6) 141-52.

[17] Akaad MK, Shazly AG, Ashmawy MH, Abdel Wahed MA. PanAfrican basement of the Wadi Abu Ghusn-Wadi Khashir district, SE Desert, Egypt, 3rd, Int. Conf. on Geol. of Arab World, Cairo, Abstract 1996.

[18] El-Sayed MM. Tectonic setting and petrogenesis of the Kadabora pluton: a late Proterozoic anorogenic A-type younger granitoid in the Egyptian Shield. Chem De Erde-Geochem 1998;(58): 38-63.

[19] Abu El Ela AM, Salem IA. Petrological and geochemical studies on the dyke swarms of the Kadabora granite pluton, Eastern Desert, Egypt. Ann Geol Surv Egypt 1999; (XXII): 47-63.

[20] Ahmed AR. Geology. Petrography, Geochemistry and Radioactivity of Kadabora area, Central Eastern Desert of Egypt. Ph.D. Thesis, South Valley Univ., Aswan branch 2002.

[21] Youssef A, Hassan A, Mohamed M. Integration of remote sensing data with the field and laboratory investigation for lithological mapping of granitic phases: Kadabora pluton, Eastern Desert, Egypt. Arab J Geosci 2009; (2): 69-82.

[22] International Atomic Energy Agency (IAEA). Guidelines for radioelement mapping using gamma ray spectrometry data. IAEATECDOC-1363, Vienna, Austria 2003; p. 173.

International Atomic Energy Agency (IAEA). Radioelement mapping. IAEA nuclear energy series, No. NF-T-1.3, Vienna, Austria 2010; p.108. 
[24] Foote R, Humphrey N. Airborne radiometric techniques and applications to U exploration. Explor U Ore Deposits 1976; 17-34.

[25] Saunders DF, Potts MJ. Interpretation and application of highsensitivity airborne gamma-ray spectrometer data. Exploration for uranium ore deposits. Proc Series. Vienna, Austria: IAEA 1976; pp.107-25.

[26] Ashmawy MH. Dike swarms and fracture pattern analyses of the Kadabora granite pluton, Eastern Desert, Egypt. ITCJ 1993; (1): 88-97.

[27] El Ramly MF, Akaad MK. The basement complex in the Eastern Desert between Lat. 2430 and 2540 N. Geol Surv Egypt 1960; paper No. 8.

[28] Ammar AA, El Kattan AM, El Sirafe AM. Aerial gamma ray spectrometric exploration of the Umm Naggat granite pluton, Eastern Desert, Egypt. Ann Geol Surv Egypt 1991; (XVII):283302.

[29] Wilford J. Airborne gamma-ray spectrometry. Geoph Remote Sens Meth Regolith Exp 2002; (144): 46-52.

[30] Friedrich M, Cuney M, Poty B. Uranium geochemistry in peraluminous leucogranites. Uranium 1987; (3): 353-85.

[31] Rogers JJW, Adams JAS. Uranium. Handbook of Geochemistry Springer-Verlag: Berlin 1969:(4).

[32] Pan G. Canonical favorability model for data integration and mineral potential mapping. Comput Geosci 1993; (19): 1077-1100.
[33] Ranjbar H, Hassanzadeh H, Torabi M, Ilaghi O. Integration and analysis of airborne geophysical data of the Darrehzar area, Kerman Province, Iran, using principal component analysis. J Appl Geophys 2001; (48): 33-41.

[34] Ranjbar H, Honarmand M, Moezifar Z. Integration and analysis of airborne geophysics and remote sensing data for exploration of porphyry copper deposits in the Central Iranian Volcanic Belt, 2003; Available from http://www.gisdevelopment.net/applicatio n/natural hazards/volcano/ma03189pf.htm

[35] Rajesh HM. Mapping Proterozoic unconformity-related uranium deposits in the Rockhole area, Northern Territory, Australia using landsat ETM+. Ore Geol Rev 2008; 33 (3): 382-96.

[36] Karimpour MH, Shafaroudi AM, Stern CR, Hidarian MR. Using ETM+ porphyry copper and epithermal gold deposits in Eastern Iran. J Appl Sci 2008; 8: 4004-16.

[37] Crosta A, Moore J. Enhancement of Landsat Thematic Mapper imagery for residual soil mapping in SW Minas Gerais State, Brazil-A prospecting case history in greenstone belt terrain. In Thematic Conference on Remote Sensing for Exploration GeologyMethods, Integration, Solutions, 7 th, Calgary, Canada 1990; pp. 1173-87.

[38] Yetkin E. Alteration Mapping By Remote Sensing: Application To Hasandağ-Melendiz Volcanic Complex. Ph.D thesis School of Natural and Applied Sciences, The Middle East Technical University 2003 .

(C) Aboelkhair et al.; Licensee Bentham Open.

This is an open access article licensed under the terms of the Creative Commons Attribution Non-Commercial License (http://creativecommons.org/licenses/by$\mathrm{nc} / 3.0 /$ ) which permits unrestricted, non-commercial use, distribution and reproduction in any medium, provided the work is properly cited. 